\title{
PENERAPAN MODEL PEMBELAJARAN COOPERATIVE INTEGRATED READING AND COMPOSITION (CIRC) UNTUK MENINGKATKAN MOTIVASI DAN HASIL BELAJAR KONSTRUKSI BANGUNAN SISWA KELAS X TGB SMK NEGERI 1 LUBUK PAKAM
}

\author{
Kintan Jenisa ${ }^{1}$, Asri Lubis ${ }^{2}$ \\ ${ }^{1}$ Alumni Program Pendidikan Teknik Bangunan, Fakultas Teknik UNIMED \\ ${ }^{2}$ Dosen Pengajar Jurusan Pendidikan Teknik Bangunan, Fakultas Teknik UNIMED \\ (asri2lbs@gmail.com)
}

\begin{abstract}
ABSTRAK
Penelitian ini merupakan Penelitian Tindakan Kelas (PTK) dengan penerapan model pembelajaran CIRC yang bertujuan untuk meningkatkan motivasi dan hasil belajar Konstruksi Bangunan pada Siswa Kelas X Program Keahlian Teknik Gambar Bangunan SMK Negeri 1 Lubuk Pakam pada semester ganjil Tahun Ajaran 2015/2016 dengan jumlah siswa 36 orang. Data penelitian diambil dari angket model skala Likert dan tes berbentuk pilihan berganda. Hasil penelitian menunjukkan nilai rata-rata motivasi belajar pada siklus I sebesar 74,86 (61,11\%) meningkat pada siklus II menjadi 82,03 $(86,11 \%)$. Selain itu, hasil belajar siswa juga mengalami peningkatan dari nilai rata-rata kognitif 75,36 $(63,89 \%)$ meningkat menjadi 81,03 (77,78\%). Maka dapat disimpulkan bahwa penerapan Model pembelajaran CIRC dapat meningkatkan Motivasi dan Hasil belajar Konstruksi Bangunan pada kompetensi dasar menerapkan spesifikasi dan karakteristik kayu untuk konstruksi bangunan Siswa Kelas X SMK Negeri 1 Lubuk Pakam.
\end{abstract}

Kata Kunci : Cooperative Integrated Reading and Composition (CIRC), Hasil Belajar, Motivasi

\begin{abstract}
This research is a classroom action research with the implementation of the CIRC learning model that aims to improve motivation and learning outcomes Building on Class X Architecture Engineering Expertise Program SMK Negeri 1 Lubuk Pakam in the first semester of the school year of 2015/2016 with the number of students 36 person. Data were taken from the questionnaire Likert scale models and multiple-choice tests. The results showed the average value of learning motivation in the first cycle of $74.86(61.11 \%)$ increased in the second cycle into $82.03(86.11 \%)$. In addition, the learning outcomes of students also increased from an average value of cognitive $75.36(63.89 \%)$ rose to $81.03(77.78 \%)$. It can be concluded that the application of the CIRC learning model can improve motivation and learning outcomes Building on the basic competencies apply specifications and characteristics of the wood for the construction of buildings Class X SMK Negeri 1 Lubuk Pakam.
\end{abstract}

Keywords: Cooperative Integrated Reading and Composition (CIRC), Learning Outcomes, Motivation 


\section{Pendahuluan}

Setiap individu secara langsung ataupun tidak langsung dituntut untuk mampu mengikuti laju perkembangan Ilmu Pengetahuan dan Teknologi (IPTEK), dan menjadi Sumber Daya Manusia (SDM) yang mampu menangani pembangunan yang senantiasa mengalami perubahan sesuai dengan kebutuhan zaman. Berbagai upaya telah dilakukan untuk menghasilkan sumber daya manusia yang berkualitas, diantaranya melalui pendidikan.

Dalam upaya peningkatan mutu pendidikan, maka pemerintah membuka Sekolah Menengah Kejuruan (SMK) dengan berbagai macam kompetensi keahlian. SMK Negeri 1 Lubuk Pakam adalah sekolah menengah kejuruan yang didirikan oleh pemerintah dan bergerak dibidang pendidikan formal. Program keahlian yang terdapat pada SMK Negeri 1 Lubuk Pakam antara lain adalah teknik bangunan, teknik ketenagalistrikan, teknik mesin, teknik otomotif, teknik elektronika, teknik komputer dan informatika, serta teknik tata kecantikan. Program keahlian teknik bangunan sendiri, terdiri dari 2 jurusan yaitu Teknik Konstruksi Kayu (TKK) dan Teknik Gambar Bangunan (TGB). Satu dari beberapa mata pelajaran produktif pada Teknik Gambar Bangunan (TGB) adalah Konstruksi Bangunan. Konstruksi Bangunan merupakan mata pelajaran produktif yang paling penting. Hal ini disebabkan mata pelajaran Konstruksi Bangunan merupakan mata pelajaran dasar untuk menunjang mata pelajaran lain seperti Gambar Konstruksi Bangunan (GKB), Menggambar Dengan Perangkat Lunak (MDPL), Gambar interior dan Eksterior Bangunan (GIDEB) dan lain sebagainya.

Berdasarkan hasil observasi dilakukan peneliti dengan guru mata pelajaran Konstruksi Bangunan, diperoleh presentasi nilai mata pelajaran Konstruksi Bangunan pada tahun ajaran $2014 / 2015$ terdapat $5,88 \%$ (2 orang) kategori sangat baik, 41,17 \% (14 orang) kategori baik, 38,24\% (12 orang) kategori cukup baik, dan $14,71 \%$ (5 orang) kategori kurang baik. Dari data tersebut dapat disimpulkan bahwa hasil belajar Mata Pelajaran Konstruksi Bangunan belum optimal.

Menurut pengamatan penulis saat melakukan observasi, ditambah dengan pengalaman penulis sewaktu melaksanakan PPLT (Program Pengalaman Lapangan Terpadu) di SMK Negeri 1 Lubuk Pakam, kebanyakan guru masih mengidolakan metode ceramah, padahal metode ini tidak memberikan stimulus kepada siswa untuk aktif dan kreatif. Selain itu siswa terlihat kurang bersemangat dalam melaksanakan proses belajar mengajar dikelas. Siswa lebih memilih diam dan tidak memberikan respon yang berarti ketika guru memberikan pertanyaan. Hal itu disebabkan karena tidak ada atau kurangnya motivasi dalam diri siswa.

Untuk itu perlu dikembangkan suatu model pembelajaran kooperatif yang mampu mendorong motivasi siswa secara menyeluruh dalam proses pembelajaran. Pembelajaran kooperatif merupakan konsep yang lebih luas meliputi semua jenis kerja kelompok termasuk bentuk-bentuk yang lebih dipimpin oleh guru atau dikerahkan oleh guru. Ada banyak jenis model pembelajaran kooperatif, diantaranya adalah Student Team Achievement Divisions (STAD), Group Investigation (GI), Examples Non Examples. Numbered Heads Together (NHT) dan Cooperative Integrated Reading and Composition (CIRC).

Dalam hal ini peneliti memilih model pembelajaran CIRC yang merupakan model pembelajaran yang menggunakan prinsip belajar kelompok. Pembelajaran kooperatif tipe CIRC dari segi bahasa dapat diartikan sebagai suatu model pembelajaran kooperatif yang mengintegrasikan suatu bacaan secara menyeluruh kemudian mengkomposisikannya menjadi bagian-bagian yang penting. Model pembelajaran kooperatif CIRC diharapkan dapat lebih memotivasi siswa untuk berinteraksi dan bereksplorasi seputar materi pembelajaran yang ada, saling membantu, berdiskusi dan berargumentasi mengemukaan idenya.

Penelitian ini dilakukan untuk mengetahui apakah penerapan model pembelajaran CIRC dapat meningkatkan motivasi dan hasil belajar. Untuk itu, penulis merasa tertarik melakukan penelitian dengan judul : " Penerapan Model Pembelajaran Cooperative Integrated Reading and Composition (CIRC) Untuk Meningkatkan Motivasi dan Hasil Belajar Konstruksi Bangunan Siswa Kelas X SMK Negeri 1 Lubuk Pakam". 


\section{Penerapan Model Pembelajaran Cooperative Integrated Reading and Composition (CIRC) Untuk meningkatkan Motivasi dan Hasil Belajar Konstruksi Bangunan Siswa Kelas X TGB SMK Negeri 1 Lubuk Pakam}

\section{Kajian Teori}

Motivasi berasal dari bahasa Latin "movere", yang berarti menggerakkan. Winkels (Siregar dan Nara, 2010 : 49) mengemukakan bahwa motivasi adalah adanya penggerak dalam diri seseorang untuk melakukan aktivitas-aktivitas tertentu demi mencapai suatu tujuan tertentu. Motivasi belajar adalah merupakan faktor psikis yang bersifat nonintelektual. Peranannya yang khas adalah dalam hal penumbuhan gairah, merasa senang dan semangat untuk belajar. Siswa yang memiliki motivasi kuat, akan mempunyai banyak energi untuk melakukan kegiatan belajar. (Sardiman, 2010 : 75). Hal ini senada dengan Suprijono (2012 : 163), bahwa motivasi belajar adalah proses yang memberi semangat belajar, arah, dan kegigihan perilaku. Artinya, perilaku yang termotivasi adalah perilaku yang penuh energi, terarah dan bertahan lama. Dari penjelasan di atas, dapat disimpulkan bahwa motivasi belajar adalah suatu dorongan atau daya penggerak dari dalam diri individu yang mengarahkan seseorang untuk melakukan usaha-usaha dalam mencapai tujuan yang dikehendaki.

Dalam buku Belajar dan Pembelajaran (Imron, 1996) yang ditulis kembali oleh Siregar dan Nara (2010 : 53-55) ada enam unsur atau faktor yang mempengaruhi motivasi dalam proses pembelajaran. Keenam faktor tersebut adalah : (a) Cita-cita / apresiasi pembelajar, (b) Kemampuan pembelajar, (c) Kondisi pembelajar, (d) Kondisi lingkungan pembelajar, (e) Unsur-unsur dinamis belajar / pembelajaran, (f) Upaya-upaya dalam membelajarkan pembelajar.

Memberikan motivasi belajar kepada seorang siswa, berarti menggerakkan siswa untuk melakukan sesuatu atau ingin melakukan sesuatu. Menurut Sardiman (2010 : 85), motivasi memiliki 3 fungsi yakni Mendorong manusia untuk berbuat, menentukan arah perbuatan, dan menyeleksi perbuatan. Hal ini sejalan dengan fungsi motivasi belajar menurut Djamarah (2008: 157) yaitu sebagai pendorong, penggerak, dan pengarah perbuatan.

Belajar merupakan sebuah kompleks yang terjadi pada semua orang dan berlangsung seumur hidup, sejak masih bayi (bahkan dalam kandungan) hingga liang lahat. Salah satu pertanda bahwa sesorang telah belajar sesuatu adalah adanya perubahan tingkah laku dalam dirinya. (Siregar dan Nara , $2010: 3$ ). Menurut Sardiman (2010 : 20), belajar itu senantiasa merupakan perubahan tingkah laku atau penampilan, dengan serangkaian kegiatan misalnya dengan membaca, mengamati, mendengarkan, meniru dan lain sebagainya. Hal ini sejalan dengan Spears (Suprijono, 2012 : 2), belajar adalah mengamati, membaca, meniru, mencoba sesuatu, mendengar dan mengikuti arah tertentu.

Salah satu definisi belajar yang cukup sederhana namun mudah diingat adalah yang dikemukakan oleh Gagne (Siregar dan Nara, 2010 : 4), belajar adalah suatu perubahan perilaku yang relatif menetap yang dihasilkan dari pengalaman masa lalu ataupun dari pembelajaran yang bertujuan direncanakan. Sedangkan belajar menurut Slameto (2003:2) sendiri adalah suatu proses usaha yang dilakukan seseorang untuk memperoleh suatu perubahan tingkah laku yang baru secara keseluruhan, sebagai hasil pengalamannya sendiri dalam interaksi dengan lingkungannya. Dari berbagai perspektif di atas, maka dapat disimpulkan bahwa belajar merupakan suatu perubahan tingkah laku yang senantiasa permanen yang terjadi pada semua orang dan berlangsung seumur hidup, seperti mengamati, membaca, meniru, mencoba sesuatu dan lain sebagainya sesuai dengan prinsip belajar itu sendiri.

Hasil belajar merupakan tolak ukur keberhasilan kegiatan belajar mengajar. Hasil belajar dapat juga dikatakan sebagai hasil akhir dari proses belajar mengajar serta merupakan perwujudan dari kemampuan diri yang optimal setelah menerima pelajaran. Menurut Sudjana (2009 : 22), hasil belajar memuat kemampuan yang dimiliki siswa setelah ia menerima pengalaman belajar. Hasil belajar menurut Suprijono (2012: 5) adalah pola-pola perbuatan, nilai-nilai, pengertian-pengertian, sikap-sikap, apresiasi dan keterampilan. Sudjana (2009 : 22) berpendapat bahwa hasil belajar adalah kemampuan-kemampuan yang dimiliki siswa setelah ia menerima pengalaman belajarnya. Sedangkan Hamalik (2009 : 90) menyatakan bahwa hasil belajar adalah terjadinya perubahan tingkah laku pada diri siswa, yang dapat diamati dalam bentuk perubahan pengetahuan, sikap, dan keterampilan. Maka dapat disimpulkan bahwa hasil belajar adalah perwujudan perilaku belajar biasanya dapat dilihat dari adanya perubahan-perubahan kebiasaan, keterampilan, dan pengetahuan, sikap dan kemampuan. 
Menurut Soekamto (Trianto, 2010) model pembelajaran adalah kerangka konseptual yang melukiskan prosedur yang sistematis dalam mengorganisasikan pengalaman belajar untuk mencapai tujuan belajar tertentu, dan berfungsi sebagai pedoman bagi para perancang pembelajaran dan para pengajat dalam merencanakan aktivitas belajar mengajar. Ada berbagai macam model pembelajaran, diantaranya adalah model pembelajaran kooperatif. Pembelajaran kooperatif (Sanjaya, 2010 : 242) merupakan model pembelajaran dengan menggunakan pengelompokan/tim kecil, yaitu antara empat sampai enam orang yang mempunyai latar belakang kemampuan akademik, jenis kelamin, ras atau suku yang berbeda (heterogen).

Model Pembelajaran Cooperative Integrated Reading and Composition (CIRC) adalah jenis model pembelajaran kooperatif. Pembelajaran kooperatif tipe CIRC ini pertama kali dikembangkan oleh Robert E. Slavin. Berdasarkan beberapa penelitian, model pembelajaran kooperatif Ini dapat memberikan pembelajaran yang lebih banyak dari pada model-model lainnya. Hal ini dikarenakan pembelajaran kooperatif dibangun atas dua perspektif teori utama yaitu perspektif motivasi dan perspektif kognitif.

Ahsan (2012) berpendapat bahwa langkahlangkah model CIRC dapat diterapkan ke dalam tahap-tahap pelaksanaannya seperti berikut :

a. Tahap pertama yaitu orientasi. Pada tahap ini, guru melakukan apresiasi dan pengetahuan awal siswa tentang materi yang akan diberikan. Selain itu juga memaparkan tujuan pembelajaran yang akan dilakukan kepada siswa.

b. Tahap kedua yaitu organisasi. Guru membagi siswa ke dalam beberapa kelompok dengan memperhatikan keheterogenan akademik. Setelah mengelompokkan siswa, kemudian guru membagi bahan bacaan tentang materi yang akan dibahas kepada siswa. Selain itu menjelaskan mekanisme diskusi kelompok dan tugas yang harus diselesaikan selama proses pembelajaran berlangsung.

c. Tahap ketiga yaitu pengenalan konsep. Dengan cara mengenalkan tentang suatu konsep baru yang mengacu pada proses pembelajaran/kegiatan kelompok, pada kegiatan ini guru menugaskan siswa untuk membaca bahan bacaan yang telah dibagikan. Setiap anggota kelompok diharuskan untuk mencari pokok permasalahan yang terdapat dalam bacaan serta sekaligus mengkritik isi (pokok permasalahan), serta saling berargument dalam kelompok untuk memastikan kritikan mereka sudah tepat dan memiliki alasan yang tepat.

d. Tahap keempat yaitu tahap publikasi. Siswa mengkomunikasikan hasil temuantemuannya dan membuktikan di depan kelas. Kelompok yang lain diharuskan untuk memberi umpan balik atas pembahasan diskusi kelompok yang sedang tampil dengan cara mengkritik pendapat/kritikan kelompok yang sedang tampil.

e. Tahap kelima yaitu tahap penguatan dan refleksi. Pada tahap ini guru memberikan penguatan berhubungan dengan materi yang dipelajari melalui penjelasanpenjelasan ataupun memberikan contoh nyata dalam kehidupan sehari-hari. Selanjutnya siswa diberi kesempatan untuk merefleksikan dan mengevaluasi hasil pembelajarannya.

Istriani (2011 : 113-114), mengemukakan bahwa model pembelajaran ini memiliki kelebihan, yaitu : (a) Membuat suasana belajar lebih menyenangkan karena siswa dikelompokkan dalam kelompok heterogen; (b) Debat membuat anak lebih rilek dalam belajar karena ditempatkan dalam kelompok yang heterogen.; (c)dapat meningkatkan kerjasama antara siswa, sebab dalam pembelajaran siswa diberikan kesempatan untuk berdiskusi dalam kelompok; (d) dengan adanya presentase akan dapat meningkatkan semangat anak untuk menjawab pertanyaan yang diajukan.

Sedangkan yang menjadi kelemahan model pembelajaran ini (Istarani, 2011 : 144), yaitu : (a) Tidak mudah guru dalam menentukan kelompok heterogen; (b) dalam diskusi, adakalanya hanya dikerjakan oleh beberapa siswa saja, sementara yang lainnya hanya sekedar pelengkap saja; (c) dalam presentase sering kurang efektif karena memakan waktu yang cukup lama sehingga tidak semua kelompok dapat mempresentasekan.

Penelitian yang relevan ditulis berdasarkan hasil riset / penelitian yang telah dilakukan peneliti lain. Penelitian yang relevan ini dinilai relevan apabila membahas topik yang sama. Berikut disajikan beberapa hasil penelitian di 


\section{Penerapan Model Pembelajaran Cooperative Integrated Reading and Composition (CIRC) Untuk meningkatkan Motivasi dan Hasil Belajar Konstruksi Bangunan Siswa Kelas X TGB SMK Negeri 1 Lubuk Pakam}

mana model yang digunakan merupakan model pembelajaran CIRC, antara lain :

Rezeky Kartika Syari (2011) dengan judul penelitian : Penerapan Model Pembelajaran Cooperative Integrated Reading and Composition (CIRC) Untuk Meningkatkan Hasil Belajar Siswa Pada Mata Diklat Bekerjasama Dengan Kolega dan Pelanggan Kelas X SMK Sri Langkat Tanjung Pura Tahun Ajaran 2010/2011. Dengan hasil penelitian bahwa penerapan model pembelajaran CIRC pada siswa kelas X SMK Sri Langkat Tanjung Pura mengalami peningkatan. Di mana pada siklus I hasil belajar tidak memenuhi standar ketuntasan belajar minimal yaitu hanya memperoleh nilai rata-rata 67,93 , sedangkan pada siklus II nilai rata-rata siswa meningkat menjadi $81,98 \%$.

Bambang Irwanto (2012) dengan judul penelitin : Penerapan Kombinasi Model Cooperative Integrated Reading and Composition (CIRC) dengan Model Course Review Horay (CRH) Terhadap Hasil Belajar Siswa Pada Materi Pokok Pertumbuhan dan Perkembangan Di Kelas VIII SMP Negeri 2 Stabat Tahun Pembelajaran 2011/2012. Dengan hasil penelitian bahwa penerapan model CIRC dan $\mathrm{CRH}$ meningkat. Peningkatan ini berdasarkan pencapaian nilai minimum pada indikator keberhasilan dari 74,52 menjadi 83,02.

Ika Valentina Br. Tarigan (2014) dengan judul penelitian : Pengaruh Model Pembelajaran Cooperative Integrated Reading and Composition (CIRC) Terhadap Kemampuan Mengkritik Isi Artikel Siswa Kelas X SMA Negeri 2 Kabanjahe Tahun Pembelajaran 2013/2014. Hasil penelitian menunjukkan kemampuan mengkritik isi artikel menggunakan metode ceramah adalah cukup dengan nilai rata-rata 72,04, sedangkan kemampuan mengkritik isi artikel dengan menggunakan model pembelajaran CIRC adalah sangat baik dengan nilai rata-rata 83,51, dan model pembelajaran CIRC berpengaruh terhadap kemampuan mengkritik isi artikel.

Eko Puji Putranto (2010) dengan judul penelitian : Penerapan Model Pembelajaran Kooperatif Tipe CIRC Berbantuan Modul Untuk Meningkatkan Motivasi Dan Hasil Belajar Siswa Kelas VIII A Mts N 1 Gemolong Tahun Ajaran 2009/2010. Dengan hasil penelitian bahwa penerapan model CIRC memberikan peningkatan terhadap motivasi dan hasil belajar Siswa Kelas VIII A Mts N 1 Gemolong. Dimana peningkatan ini berdasarkan pemberian angket motivasi dari nilai 60,23 menjadi 87,56 serta pada indikator tes hasil belajar dari 68,52 menjadi 85,62.

Berdasarkan penelitian relevan di atas, dapat disimpulkan bahwa model pembelajaran CIRC dapat meningkatkan motivasi dan hasil belajar siswa dibandingkan dengan perilaku pembelajaran sebelumnya yang masih menerapkan pembelajaran individual maupun pembelajaran yang berpusat pada guru.

\section{Metodologi Penelitian}

Penelitian ini dilaksanakan di SMK Negeri 1 Lubuk Pakam yang beralamatkan di jalan Galang Kabupaten Deli Serdang Kecamatan Lubuk Pakam pada semester ganjil tahun ajaran 2015/2016. Kegiatan penelitian dilakukan pada tanggal 18 November 2015 - 27 November 2015. Subjek penelitian ini adalah siswa kelas X Program Keahlian Teknik Gambar Bangunan di SMK Negeri 1 Lubuk Pakam Tahun Ajaran 2015/2016 dengan jumlah siswa sebanyak 36 siswa, sedangkan objek penelitian adalah Penerapan Model Pembelajaran Cooperative Integrated Reading and Composition Untuk Meningkatkan Motivasi dan Hasil Belajar Konstruksi Bangunan Siswa Kelas X Program Keahlian Teknik Gambar Bangunan SMK Negeri 1 Lubuk Pakam.

Penelitian ini dilakukan dengan menggunakan model Penelitian Tindakan Kelas (PTK) dengan tahapannya sebagai berikut :

Perencanaan Tindakan (Planning). Pada tahapan perencanaan ini, peneliti bersama guru bidang studi Konstruksi Bangunan mengadakan pembahasan tentang teknis pelaksanaan penelitian tindakan kelas, membuat tes hasil belajar, membuat Rencana Pelaksanaan Pembelajaran (RPP) sesuai dengan model pembelajaran yang akan digunakan dalam peneliti.

Pelaasanaan (Acting). Pada tahap ini, guru melaksanakan kegiatan pembelajaran dengan menggunakan tahapan model pembelajaran CIRC sesuai dengan RPP yang telah direncanakan. Setelah penerapan model pembelajaran CIRC selesai dilaksanakan, maka langkah selanjutnya adalah melakukan evaluasi belajar dengan memberikan tes motivasi berupa angket, tes hasil belajar ranah kognitif berupa tes objektif serta tes hasil belajar ranah afektif dan psikomotorik berupa angket 
penilaian diri. untuk melihat tingkat keberhasilan yang dicapai oleh siswa.

Pengamatan (Observation). Pengamatan dilakukan oleh peneliti saat kegiatan belajar mengajar berlangsung. Hal yang diamati adalah kegiatan siswa baik yang mendukung proses belajar mengajar maupun yang tidak mendukung proses belajar mengajar. Pada tahap pengamatan, peneliti juga mengawasi kegiatan belajar mengajar agar berjalan sesuai tahapan yang telah direncanakan.

Refleksi (Reflection). Refleksi dilakukan berdasarkan hasil analisis data, perolehan tes dan observasi yang dilakukan. Dalam hal ini, jika seluruh maupun melebihi 75\% dari jumlah siswa telah mencapai Kriteria Ketuntasan Minimum $(\mathrm{KKM}) \geq 75$, maka penerapan model pembelajaran CIRC dalam penelitian ini dikatakan mengalami peningkatan atau berhasil. Apabila penerapan model pembelajaran CIRC tidak berhasil atau tidak mengalami peningkatan maka dari hasil refleksi ini dapat ditentukan tindakan perbaikan pada tahap perencanaan siklus berikutnya.

Instrumen pengumpulan data motivasi belajar dijaring dengan menggunakan angket model Skala Likert yang telah dimodifikasi. Penggunaan angket model Likert ini terdiri dari empat jawaban yang merentang dari "Sangat Setuju" sampai pada "Sangat Tidak Setuju" yang berjumlah 29 butir soal. Adapun Instrumen hasil belajar Konstruksi bangunan ranah kognitif menggunakan tes hasil belajar berbentuk multiple choice dengan jumlah 20 butir pada siklus I dan 21 butir pada siklus II. Sedangkan Instrumen tes hasil belajar ranah afektif dan psikomotorik menggunakan lembar penilaian diri.

\section{Hasil dan Pembahasan}

Pada penelitian ini pembelajaran dilakukan dalam dua siklus di mana pada setiap siklus dilakukan dalam 2 pertemuan. Tiap siklus terdiri dari empat tahap yaitu perencanaan (planning), pelaksanaan (acting), pengamatan (observing), dan refleksi (reflecting).

Siklus pertama. Pada tahap perencanaan Menyusun Rencana Pelaksanaan Pembelajaran (RPP) dengan penerapan model pembelajaran CIRC, mempersiapkan format penilaian diri, angket dan tes hasil belajar, mempersiapkan alat dan bahan yang akan digunakan dalam proses pembelajaran.
Pada tahap pelaksaaan, siklus I dilaksanakan sebanyak 2 kali pertemuan yaitu pada hari Rabu 18 November 2015 dengan durasi waktu $3 \times 45$ menit dan hari Jum'at 20 November 2015 dengan durasi waktu $4 \times 45$ menit. Masing-masing pertemuan dilaksanakan dalam tiga tahapan kegiatan belajar yaitu pendahuluan, inti dan penutup.

Pada pertemuan pertama, yaitu pada tahap pendahuluan, guru membuka pelajaran dengan memberi salam dan berdoa. Selanjutnya guru bersama siswa melaksanakan senam otak disusul dengan memberikan motivasi kepada siswa. Kemudian guru mengajukan beberapa pertanyaan tentang spesifikasi dan karekteristik kayu serta bagian-bagian kayu dan fungsinya dan mengenalkan siswa tentang model pembelajaran CIRC beserta langkahlangkahnya. Tahap pendahuluan membutuhkan waktu 15 menit.

Pada tahap inti, yaitu pelaksanaan model pembelajaran CIRC. Guru membagi siswa menjadi beberapa kelompok yang beranggotakan 5 orang secara heterogen. Selanjutnya guru bersama peneliti memberikan materi pelajaran kepada setiap kelompok, serta menugaskan setiap kelompok untuk membaca materi yang dibagikan dan bertanggungjawab untuk mempelajarinya. Kemudian guru menugaskan masing-masing kelompok mencari pokok permasalahan sekaligus mengkritik pokok permasalahan tersebut. Selanjutnya setiap kelompok diminta untuk mempersentasikan hasil diskusi masing-masing kelompok. Kegiatan ini membutuhkan waktu sekitar 105 menit.

Adapun pada tahap penutup, guru bersama siswa mengevaluasi seluruh rangkaian aktivitas pembelajaran dengan menugaskan siswa membuat kesimpulan atas materi yang telah selesai dipersentasikan. Kemudian guru menutup kegiatan belajar mengajar dengan salam dan berdoa. Kegiatan penutup membutuhkan waktu sekitar 15 menit.

Pada pertemuan kedua, guru membuka pelajaran dengan memberikan salam dan berdoa. Kemudian me-review ingatan siswa dengan mengajukan beberapa pertanyaan tentang pembelajaran sebelumnya. Selanjutnya guru memberikan informasi awal berupa lanjutan materi yang akan dipelajari yaitu jenisjenis kayu dan kerusakan kayu. Selama kegiatan pendahuluan berlangsung, guru memberikan motivasi kepada siswa berupa 


\section{Penerapan Model Pembelajaran Cooperative Integrated Reading and Composition (CIRC) Untuk meningkatkan Motivasi dan Hasil Belajar Konstruksi Bangunan Siswa Kelas X TGB SMK Negeri 1 Lubuk Pakam}

gambaran manfaat materi. Tahap pendahuluan ini membutuhkan waktu sekitar 15 menit.

Tahap inti, guru menugaskan siswa membentuk kelompok berdasarkan pembagian kelompok pertemuan sebelumnya. Kemudian guru dan siswa melakukan tahap inti dengan langkah-langkah seperti pada tahap inti pertemuan sebelumnya. Hanya saja pada tahap inti pertemuan kedua ini, siswa mendiskusikan materi yang berbeda yaitu tentang jenis-jenis kayu dan kerusakan kayu. Tahap ini membutuhkan waktu sekitar 105 menit.

Tahap penutup pada model pembelajaran CIRC yaitu dengan cara mengevaluasi seluruh rangkaian aktivitas pembelajaran. Kemudian guru memberikan tes hasil belajar berupa tes objektif untuk ranah kognitif, tes penilaian diri untuk ranah afektif dan psikomotorik, serta non tes angket untuk mengukur motivasi belajar siswa. Pengerjaan tes dan non tes beserta penutup membutuhkan waktu 60 menit.

Kegiatan observasi dilakukan selama proses belajar mengajar berlangsung. Selama observasi, peneliti mengamati proses belajar mengajar agar berlangsung sesuai dengan tahapan yang telah direncanakan.

Adapun pada tahap refleksi, didapat beberapa kelebihan dan kekurangan. Kekurangan pada siklus I antara lain : Siswa masih belum terbiasa dengan kondisi pembelajaran yang menerapkan model pembelajaran CIRC. Sebagian siswa belum memahami langkah-langkah model pembelajaran CIRC secara utuh dan menyeluruh. Motivasi siswa pada siklus I belum optimal. Hal ini terlihat motivasi ratarata siswa pada siklus I yaitu 74,86 dengan presentase bermotivasi tinggi dan sangat tinggi hanya mencapai $61,11 \%$. Hasil belajar ranah kognitif siswa pada siklus I dilihat dari hasil tes objektif yang diberikan mencapai rata-rata $75,06(63,09 \%)$. Hasil belajar ranah afektif mencapai rata-rata $76,11 \quad(66,57 \%)$. Adapun keberhasilan yang dicapai pada siklus I ini adalah : Siswa lebih antusias dalam belajar. Tiap kelompok terlihat aktif dalam berdiskusi. Hasil belajar ranah psikomotorik siswa pada siklus I mencapai rata-rata 77,64 (75\%). Maka berdasarkan hal tersebut, siklus II perlu dilaksanakan.

Siklus II. Pada tahap perencanaan diperoleh bahwa pelaksanaan yang akan dilakukan pada siklus kedua akan difokuskan pada hasil belajar yang belum mencapai keberhasilan.

Pada siklus II dilaksanakan sebanyak 2 kali pertemuan yaitu pada hari Kamis 26 November 2015 dengan durasi waktu $3 \times 45$ menit dan hari Jum'at 27 November 2015 dengan durasi waktu $4 \times 45$ menit. Masing-masing pertemuan dilaksanakan dalam tiga tahapan kegiatan belajar yaitu pendahuluan, inti dan penutup.

Pada pertemuan ketiga, yaitu pada tahap pendahuluan, guru membuka pelajaran dengan memberi salam dan berdoa, melaksanakan senam otak disusul dengan memberikan motivasi dan mengajukan beberapa pertanyaan seputar materi yang akan dibahas. Guru kembali mengenalkan siswa tentang model pembelajaran CIRC beserta langkahlangkahnya. Mengingat hasil refleksi pada siklus I bahwa masih banyak siswa yang belum terbiasa dengan kondisi belajar kooperatif terutama dalam penerapan model pembelajaran CIRC. Tahap pendahuluan membutuhkan waktu lebih kurang 15 menit.

Pada tahap inti, yaitu pelaksanaan model pembelajaran CIRC. Guru membagi siswa menjadi beberapa kelompok yang beranggotakan 5 orang secara heterogen. Selanjutnya guru bersama peneliti memberikan materi pelajaran kepada setiap kelompok, serta menugaskan setiap kelompok untuk membaca materi yang dibagikan dan bertanggungjawab untuk mempelajarinya. Kemudian guru menugaskan masing-masing kelompok mencari pokok permasalahan sekaligus mengkritik pokok permasalahan tersebut. Selanjutnya setiap kelompok diminta untuk mempersentasikan hasil diskusi masing-masing kelompok dan melakukan tanya jawab. Kegiatan ini membutuhkan waktu sekitar 105 menit.

Adapun pada tahap penutup, guru bersama siswa mengevaluasi seluruh rangkaian aktivitas pembelajaran dengan menugaskan siswa membuat kesimpulan, kemudian guru menutup kegiatan belajar mengajar dengan salam dan berdoa. Kegiatan penutup membutuhkan waktu sekitar 15 menit.

Pada pertemuan keempat, guru membuka pelajaran dengan memberikan salam dan berdoa. Kemudian me-review ingatan siswa dengan mengajukan beberapa pertanyaan tentang pembelajaran sebelumnya. Selanjutnya guru memberikan informasi awal berupa lanjutan materi yang akan dipelajari yaitu cara pengawetan dan proses pengolahn kayu hasil 
olahan. Selama kegiatan pendahuluan berlangsung, guru memberikan motivasi kepada siswa. Tahap pendahuluan ini membutuhkan waktu sekitar 15 menit.

Tahap inti, guru menugaskan siswa membentuk kelompok berdasarkan pembagian kelompok pertemuan sebelumnya. Kemudian guru dan siswa melakukan tahap inti dengan langkah-langkah seperti pada tahap inti pertemuan sebelumnya. Hanya saja pada tahap inti pertemuan keempat ini, siswa mendiskusikan materi yang berbeda yaitu tentang cara pengawetan dan proses pengolahn kayu hasil olahan. Tahap ini membutuhkan waktu sekitar 105 menit.

Tahap penutup pada model pembelajaran CIRC yaitu dengan cara mengevaluasi seluruh rangkaian aktivitas pembelajaran dan hasilhasil yang diperoleh dalam bentuk catatan. Kemudian guru memberikan tes hasil belajar berupa tes objektif untuk ranah kognitif, tes penilaian diri untuk ranah afektif dan psikomotorik, serta non tes angket untuk mengukur motivasi belajar siswa. Pengerjaan tes dan non tes beserta penutup membutuhkan waktu 60 menit.

Kegiatan observasi dilakukan selama proses belajar mengajar berlangsung. Selama observasi, peneliti mengamati proses belajar mengajar agar berlangsung sesuai dengan tahapan yang telah direncanakan. Adapun pada tahap refleksi dapat diketahui bahwa keberhasilan pada siklus II telah tercapai. Hal ini terlihat dari rata-rata motivasi belajar siswa pada mencapai $82,03(77,78 \%)$, rata-rata hasil belajar ranah kognitif 82,03 (77,78\%), ranah afektif $82,31(86,11 \%)$ serta ranah psikomotorik 82,17 (83,33\%). Berikut ini adalah diagram perbandingan siklus I dan siklus II.

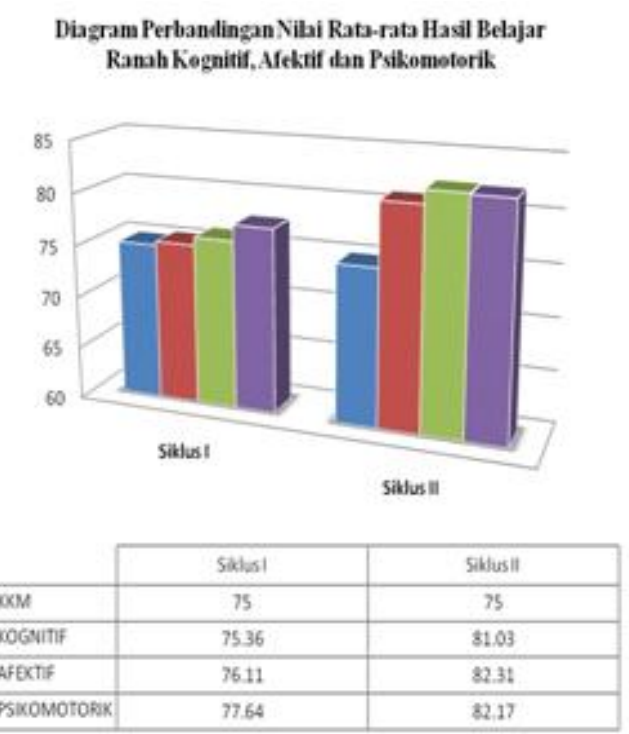

Gambar 1. Diagram Perbandingan Hasil Belajar Ranah Kognitif, Afektif, dan Psikomotorik
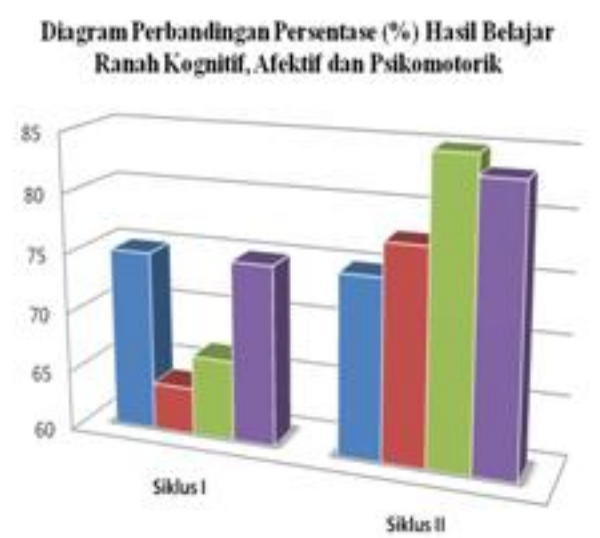

\begin{tabular}{|c|c|c|}
\hline & ShlusI & Sabsil \\
\hline MOM & 75 & 73 \\
\hline - KOGNITH & 63.89 & 77.78 \\
\hline$=A F E C T F$ & 66.67 & 85.11 \\
\hline - PSIKOMOTOFIK & 75.00 & 83.33 \\
\hline
\end{tabular}

Gambar 2. Diagram Perbandingan Persentase

$\begin{array}{lrr}(\%) \quad \text { Hasil Belajar } & \text { Ranah } \\ \text { Kognitif, } & \text { Afektif, } & \text { dan } \\ \text { Psikomotorik } & & \end{array}$

Dari hasil penelitian pada Siklus II di atas, maka dapat disimpulkan bahwa motivasi dan hasil belajar siswa telah KKM yaitu 75 dengan rata-rata presentase $\geq 75 \%$, oleh karena itu siklus selanjutnya tidak perlu dilakukan lagi.

5. Kesimpulan dan Saran 


\section{Penerapan Model Pembelajaran Cooperative Integrated Reading and Composition (CIRC) Untuk meningkatkan Motivasi dan Hasil Belajar Konstruksi Bangunan Siswa Kelas X TGB SMK Negeri 1 Lubuk Pakam}

\subsection{Kesimpulan}

Berdasarkan hasil dan pembahasan penelitian, dapat ditarik beberapa kesimpulan yaitu sebagai berikut :

a. Penerapan model pembelajaran Cooperative Integrated Reading and Composition (CIRC) dapat meningkatkan motivasi belajar siswa mata pelajaran Konstruksi Bangunan pada Siswa Kelas X Program Keahlian Teknik Gambar Bangunan SMK Negeri 1 Lubuk Pakam. Hal ini dapat dilihat pada perbandingan motivasi belajar siswa yang mengalami peningkatan, yaitu pada siklus I dengan nilai motivasi rata-rata 74,86 $(61,11 \%)$ meningkat menjadi 82,03 $(86,11 \%)$ pada siklus II.

b. Penerapan model pembelajaran Cooperative Integrated Reading and Composition (CIRC) dapat meningkatkan hasil belajar konstruksi bangunan pada Siswa Kelas X Program Keahlian Teknik Gambar Bangunan SMK Negeri 1 Lubuk Pakam. Hal ini dapat dilihat pada perbandingan rata-rata hasil belajar siswa baik pada ranah kognitif, afektif maupun psikomotorik. Pada ranah kognitif, hasil belajar siswa mengalami peningkatan, yaitu pada siklus I dengan nilai kognitif rata-rata 75,36 $(63,89 \%)$ meningkat menjadi 81,03 $(77,78 \%)$ pada siklus II. Pada ranah afektif juga mengalami peningkatan, yaitu pada siklus I dengan nilai afektif rata-rata 76,11 $(66,67 \%)$ meningkat menjadi 82,31 $(86,11 \%)$ pada siklus II. Sedangkan pada ranah psikomotorik rata-rata $77,64(75,00 \%)$ meningkat menjadi $82,17(83,33 \%)$ pada siklus II.

\subsection{Saran}

Setelah melihat hasil penelitian, pembahasan dan kesimpulan maka peneliti memberikan saran sebagai berikut :

a. Bagi Siswa.

Diharapkan kepada siswa untuk lebih memberanikan diri dalam bertanya apabila penjelasan guru terhadap tahapan model pembelajaran CIRC belum dapat dipahami, hal ini guna memudahkan siswa untuk mengikuti proses belajar sehingga berdampak positif bagi hasil belajar siswa itu sendiri. Selain itu, peneliti menyarankan pula agar siswa lebih percaya diri dalam menyampaikan pendapat, serta dapat menghargai pendapat orang lain apabila terjadi perbedaan pendapat.

b. Bagi Guru.

Guru sebaiknya menjadikan model pembelajaran CIRC sebagai suatu alternatif untuk meningkatkan motivasi dan hasil belajar siswa pada mata pelajaran Konstruksi Bangunan. Namun pada penerapannya, guru diharapkan agar memiliki persiapan yang baik dan memberikan perhatian lebih pada tahap memperkenalkan model pembelajaran kepada siswa, guru harus dapat memastikan bahwa siswa telah mengerti tahapan model pembelajaran CIRC, sehingga pembelajaran dapat berjalan dengan baik dengan waktu yang lebih efektif.

c. Bagi Kepala Sekolah.

Diharapkan terus mendukung pelaksanaan penelitian lainnya sebagai referensi yang dapat digunakan oleh para guru di SMK Negeri 1 Lubuk Pakam khususnya guru mata pelajaran Konstruksi Bangunan guna sebagai salah satu sarana dalam meningkatkan mutu pembelajaran di sekolah terutama dalam peningkatan motivasi dan hasil belajar siswa.

d. Bagi Mahasiswa.

Mahasiswa selaku peneliti selanjutnya dapat menggunakan judul yang sama untuk dijadikan suatu studi perbandingan bagi guru dalam meningkatkan kualitas pendidikan khususnya pada mata pelajaran Konstruksi Bangunan.

\section{Daftar Pustaka}

Ahsan, Afriadi. (2012). Model Pembelajaran Kooperatif Tipe Cooperative Integrated Reading And Compocition (CIRC). Diakses pada 02 Maret 2015 dari http://modelpembelajarankooperatif.blogspot.c om/2012/08/circ.html.

Djamarah, S.B. (2008). Psikologi Belajar. Jakarta : Rineka Cipta

Hamalik, Oemar. (2009). Psikologi Belajar dan Mengajar. Bandung: Sinar Baru Algensindo.

Irwanto, Bambang. (2012). Penerapan Kombinasi Model Cooperative Integrated 
Reading and Composition (CIRC) dengan

Model Course Review Horay (CRH)

Terhadap Hasil Belajar Siswa Pada

Materi Pokok Pertumbuhan dan

Perkembangan di Kelas VII SMP Negeri 2

Stabat Tahun Pembelajaran 2011/2012.

Skripsi Sarjana, tidak diterbitkan, Universitas Negeri Medan, Medan.

Istarani. (2011). 58 Model Pembelajaran Inovatif. Medan : Media Persada.

Putranto, E.P. (2010). Penerapan Model Pembelajaran Kooperatif Tipe CIRC Berbantuan Modul Untuk Meningkatkan Motivasi Dan Hasil Belajar Siswa Kelas VIII A Mts N 1 Gemolong Tahun Ajaran 2009/2010. Skripsi Sarjana, tidak diterbitkan, Universitas Sebelas Maret, Surakarta.

Sanjaya, Wina. (2010). Perencanaan dan Desain Sistem Pembelajaran. Jakarta : Kencana.

Sardiman. (2010). Interaksi dan Motivasi Belajar Mengajar. Jakarta : Rajawali Pers.

Siregar dan Nara. (2010). Teori Belajar dan Pembelajaran. Bogor : Ghalia Indonesia.

Slameto. (2003). Belajar dan Faktor-faktor yang Mempengaruhinya. Jakarta: Rineka.

Sudjana. N. (2009). Penilaian Hasil Belajar Mengajar. Bandung : PT Remaja Rosdakarya.

Syari, R.K. (2011). Penerapan Model Pembelajaran Cooperative Integrated Reading and Composition (CIRC) Untuk Meningkatkan Hasil Belajar Siswa Pada Mata Diklat Bekerjasama Dengan Kolega dan Pelanggan Kelas X SMK Sri Langkat Tanjung Pura Tahun Ajaran 2010/2011. Skripsi Sarjana, tidak diterbitkan, Universitas Negeri Medan, Medan.

Suprijono, Agus. (2012). Cooperative Learning Teori dan Aplikasi PAIKEM. Yogjakarta : Pustaka Pelajar.

Tarigan, I.V. (2014). Pengaruh Model Pembelajaran Cooperative Integrated Reading and Composition (CIRC) Terhadap Kemampuan Mengkritik Isi Artikel Kelas X SMA Negeri 2 Kabanjahe Tahun Pelajaran 2013/2014. Skripsi Sarjana, tidak diterbitkan, Universitas Negeri Medan, Medan.

Trianto. (2010). Mendesain Model Pembelajaran Inovatif Progresif: Konsep, Landasan, dan Implementasinya pada Kurikulum Tingkat Satuan Pendidikan. Jakarta : Kencana Prenada Media Group. 